THE END OF AUSTRIA-HUNGARY. By Leo Valiani. New York: Alfred A. Knopf, 1973. xiii, 474 pp. $\$ 15.00$.

AMERICA, ITALY AND THE BIRTH OF YUGOSLAVIA (1917-1919). By Dragan R. Żivojinović. East European Monographs, no. 2. Boulder: East European Quartcrly, 1972. Distributed by Columbia University Press, New York. 338 pp. $\$ 10.00$.

The basic point of Leo Valiani's magisterial study of the end of Austria-Hungary is that the empire collapsed because its governing class was consistently unable to make the painful decisions which survival required. This is not a new suggestion, but in Valiani's hands it is a powerful one. His complex prose, his intimate familiarity with materials in all languages of the empire, and his insistence on avoiding facile judgments have allowed him to create a book whose richness is a reflection of the richness of the subject.

Each chapter is a minor study in itself. Chapter 2, for example, discusses Italy's entrance into World War I. Valiani does not agree that Italy's participation on the side of the Entente was inevitable, or that the question was decided before the beginning of 1915, as Renzi has suggested. He argues that Austrian timidity prevented Giolitti from provoking a governmental crisis in the spring of 1915 in order to impose his policy of nonintervention, even though he probably could have mustered a majority in parliament. The Austrian leadership simply could not bring itself to grant Italy immediate territorial compensations in the Trentino and elsewhere in return for a free hand in the Balkans. Valiani also demonstrates that Sonnino's belief in the duplicity of the Austrians was amply justified. Even in the face of the virtual certainty that Italy would soon become a belligerent, each grudging step in Vienna was hedged with private vows to undo any concessions as soon as the war was over.

Quite naturally, Valiani concentrates on the Italian aspects of his subject. For example, he disposes of Rumania's decision to enter the war, which he considers a "decisive step towards the dismemberment of the Danubian Monarchy," simply by saying that it occurred "after nearly two years of pulling this way and that." But he more than compensates for this weighting by his detailed analysis of those subjects he does discuss. Particularly strong themes are the South Slav question, so closely connected to Italian issues, and the internal play of AustroHungarian politics.

In the case of the South Slavs, the remarkable thing, despite the activities abroad of Supilo, was the loyalty of Croatian and Slovenian political leaders to the monarchy in the face of war-weariness and deprivation. In 1917 these politicians, in cooperation with the Czechs, were still demanding reform within the empire, not its break-up. As Valiani's analysis suggests, however, the opportunity for saving the empire which this attitude implied was apparent, not real. How could leaders such as Emperor Charles and Count Czernin, let alone intransigents such as Tisza, grasp the nettle of federal reform or separate peace when even the radicals who opposed them could not? The Social Democrats refused to seize power in Austria as late as January and February 1918, when widespread strikes gave them at least a chance to do so. Even Károlyi could not convince his own party to give up the dogma of territorial integrity less than a year before Hungary disintegrated. Perhaps the Monarchy could have been saved, but Valiani makes a good case that almost no one in a position to force such radical measures was adequate to the task. 
Valiani's book has been translated into English from the original Italian edition of 1966 (two important new appendixes have been added). Živojinović's book, however, apparently was written originally in English. Since this is not his native language, it is difficult to say whether the malapropisms, faulty organization, tedious writing, and muffled points are the result of language deficiencies or of conceptual problenis. The author's purpose is to flesh out the relation between Americit and Italy during the crucial period between April 1917 and April 1919, and to re-emphasize the impact of $W$ ilson on Eastern Europe. He brings forward some interesting data on American aid to Italy during the war and on food relief afterward, and he shows how the actions of the American navy in the Adriatic helped establish a de facto American policy hostile to Italy after the Armistice. But his interpretation of Wilson's impact, his view that the Armistice negotiations in Paris represented a crucial lost opportunity to defiect Italy in the Adriatic, and other smaller points are not argued with sufficient clarity and force to be convincing. Therefore, despite the new data Živojinovic introduces, his book is not likely to leave as lasting an impression on the scholarship of this period as Valiani's detailed and subtle study.

\section{Gale Stokes}

Rice University

YUGOSLAVIA: BEFORE THE ROMAN CONQUEST. By John Alexander. Ancient Peoples and Places, no. 77. New York and Washington: Praeger Publishers, 1972. Illus. 175 pp. $\$ 12.50$.

Obviously, the Ancient Peoples and Places series is intended to provide summaries of archeological data from particular geographic locations and time periods. Thus this book presents a summary of the archeological data on Yugoslavia from the earliest human occupation to the Roman Conquest. The five chapters of the book deal successively with the Paleolithic and Mesolithic periods, the Neolithic, the Early Bronze Age, the Middle and Late Bronze Age, and the pre-Roman Iron Age. Each of the chapters presents essentially a catalogue of the known data for that period. Each also contains a map, a list of sites, and various illustrations. Sixteen pages of plates follow the text.

The main purpose of compiling this summary is apparently to prepare a "history" of Yugoslavia from archeological (that is, prehistoric) materials. As Dr. Alexander points out at the beginning of chapter 5, this is easiest to do for the pre-Roman Iron Age, because "Jugoslavia was a close neighbour of civilized, literate, urban peoples in both Italy and Greece" (p. 98). For the earlier time periods presumably this is more difficult to do. I would suggest that it is, in fact, impossible to do, because "historic" events are not preserved in the archeological record. Archeological data from historic time periods may be correlated with recorded history, but historic events cannot be discovered archeologically. Archeological data (certainly from prehistoric time periods) are much more amenable to the analysis of the adaptations of prehistoric populations. In addition, these data are equally appropriate for the analysis of the techno-economic development of prehistoric populations. Unfortunately the "catalogue" format of the books in this series allows for very little discussion of human adaptations or technoeconomic development.

It seems that books in the Ancient Peoples and Places series are directed at two audiences simultaneously: students of archeology and history, and the general 